Aneta Dawidowicz

Uniwersytet Marii Curie-Skłodowskiej w Lublinie

\title{
POZYCJA USTROJOWA WŁADZY WYKONAWCZEJ W ŚWIETLE POGLĄDÓW IDEOLOGÓW STRONNICTWA NARODOWEGO DO 1939 ROKU $^{1}$
}

W literaturze przedmiotu dominuje przekonanie, że nacjonalizm we współczesnym tego słowa rozumieniu pojawił się w drugiej połowie XIX wieku. Wtedy to w całej niemal Europie nastąpił rozwój licznych ruchów politycznych, opierających swe programy na jego założeniach ${ }^{2}$. Narodowa Demokracja stanowiła główną, lecz nie jedyną, zorganizowaną siłę nurtu nacjonalistycznego w polskim życiu politycznym. Pełniła ważną rolę w dziejach Polski, występując jako istotny czynnik polityczny i twórczy ośrodek polskiej myśli politycznej. Formacje o charakterze nacjonalistycznym zajmowały poczesne miejsce w życiu politycznym II Rzeczypospolitej. Trzon organizacyjny Narodowej Demokracji tworzyły - Związek Ludowo-Narodowy (1919-1928), Obóz Wielkiej Polski (1926-1933), Stronnictwo Narodowe (1928-1939).

Wkład ideowy Stronnictwa Narodowego do dorobku myśli politycznej obozu narodowego, a w szerszym wymiarze - do polskiej myśli politycznej był znaczący. Myśl polityczna SN obejmowała szeroki kompleks zagadnień ideowych, politycznych, ustrojowych, historiozoficznych, filozoficznych, pedagogicznych, społecznych, gospodarczych. Twórcy myśli politycznej SN wypracowali wizję wielu kategorii z zakresu myśli politycznej, między innymi takich kluczowych jak: naród, państwo, władza polityczna, gospodarka, społeczeństwo, wychowanie narodowe, stosunek do katolicyzmu, status mniejszości narodowych, polityka zagraniczna, bezpieczeństwo.

W okresie międzywojennym w większości państw europejskich można dostrzec skłonność do modyfikacji założeń Monteskiusza o podziale władz na trzy rodzaje: ustawodawczą, wykonawczą, sądowniczą. Adaptacja dotychczasowych rozwiązań

Tekst został opracowany w ramach projektu badawczego „Myśl polityczna Stronnictwa Narodowego (1928-1939)” finansowanego ze środków Narodowego Centrum Nauki przyznanych na podstawie decyzji numer 2013/09/B/ HS5/00016.

2 J.M. Majchrowski, Nacjonalizm jako sposób myślenia, (w:) Prawo i polityka, A. Bodnar, J. Wróblewski (red.), Warszawa 1988 , s. 358. 
ustrojowych prowadziła w kierunku wzmocnienia organów wykonawczych. Można uznać, że odzwierciedleniem tych procesów były poglądy ustrojowe SN. Stosunek do organów wykonawczych określała myśl o konieczności stworzenia ustroju narodowego. Namysł nad charakterem organów wykonawczych skłaniał do wniosku, że powinny one gwarantować siłę władzy i należny jej autorytet. SN opowiadało się za wprowadzeniem takich rozwiązań konstytucyjnych, które 1) zabezpieczałyby trwałość i stałość rządów; 2) zapobiegałyby nazbyt częstym zmianom rządowym. Projekt SN utrzymywał zasadę parlamentarnej odpowiedzialności rządu. Stałe miejsce zajmował postulat trwałości rządów.

W myśli politycznej SN podejmowano problem pozycji i roli głowy państwa. Uważano, że stanowisko głowy państwa powinno być otoczone najwyższą powagą i szacunkiem. Głowa państwa, w opinii ideologów partii, stanowiła ważny organ władzy. Przewidywano dlań rolę przedstawiciela państwa politycznie przed nikim nie odpowiadającego. W oświadczeniach przedstawicieli zarówno starego, jak i młodego pokolenia SN stale powtarzało się przekonanie, że głowa państwa powinna cieszyć się należnym autorytetem i posłuchem u obywateli³.

Przedmiotem zainteresowania polityków SN, była instytucja polityczna prezydenta, jej konstytucyjne usytuowanie, tryb powoływania, uprawnienia, odpowiedzialność oraz relacje $\mathrm{z}$ pozostałymi organami władzy państwowej. Ocena rzeczywistości politycznej obejmowała charakterystykę osób sprawujących najwyższy urząd w państwie, ich osobowości i cechy charakteru, merytoryczne kwalifikacje. Mimo obaw, że najwyższe stanowisko w państwie mogłaby objąć niepożądana jednostka, nieustannie podkreślano konieczność wzmocnienia głowy państwa ${ }^{4}$. Akceptacja silnych organów wykonawczych nie oznaczała jednak bezwzględnego poparcia dla koncepcji silnej prezydentury. W dużej mierze takie stanowisko wynikało z uwarunkowań bieżącej taktyki politycznej5.

Wydarzenia związane z przewrotem majowym i przejęciem władzy przez formację piłsudczykowską skłoniły Narodową Demokrację do sprecyzowania stanowiska wobec uprawnień prezydenta. Nie zmieniono poglądów na temat postulowanego jeszcze przed zamachem majowym wzmocnienia konstytucyjnej pozycji prezydenta. Domagano się nadania prezydentowi większych uprawnień ${ }^{6}$. Krytyczne opinie wzbudzał fakt, że obowiązująca dotychczas zasada suwerenności narodu, delegującego władzę w ręce powołanych przez siebie organów, została zastąpiona przez ideę państwa. Zgodnie z postanowieniami Konstytucji kwietniowej prerogatywy narodu

3 R. Piestrzyński, Kryzys ustrojowy i jego rozwiązanie, „Awangarda” 1928, nr 7, s. 164, s. 165.

4 W. Komarnicki, O konstytucję narodową. Stanowisko Stronnictwa Narodowego w sprawie rewizji konstytucji oraz tekst projektu rewizji złożonego przez Klub Narodowy w Komisji Konstytucyjnej Sejmu, Warszawa 1930, s. 18. Cyt. za: G. Radomski, Samorząd terytorialny w myśli politycznej Narodowej Demokracji 1918-1939, Toruń 2009, s. 68.

6 M. Białokur, Myśl społeczno-polityczna Joachima Bartoszewicza, Toruń 2005, s. 205. 
przelane zostały na głowę państwa. Prezydent miał być piastunem władzy jednolitej i niepodzielnej, nieodpowiadającej przed nikim za swe czynności ${ }^{7}$.

W programie SN z października 1928 roku z szacunkiem pisano na temat głowy państwa. Jednak zdecydowana chęć wzmocnienia pozycji prezydenta, obecna w enuncjacjach prasowych endeków jeszcze przed 1926 rokiem została zastąpiona przez bardziej enigmatyczne określenia. Zdawano sobie bowiem sprawę, że kandydat obozu narodowego miał niewielkie szanse na objęcie najwyższego urzędu w państwie ${ }^{8}$.

Zgłoszony przez SN projekt dążył do wzmocnienia organów wykonawczych ${ }^{9}$. $\mathrm{SN}$ opowiadało się za rozszerzeniem uprawnień prezydenta ${ }^{10}$. Za konieczne uznano wyposażenie prezydenta w prawo veta ustawodawczego. Czynny udział prezydenta w pracach rządu miał być środkiem umacniającym jego pozycję. Wielokrotnie pojawiał się postulat, że stanowisko głowy państwa powinno być otoczone najwyższą powagą i szacunkiem. Głowę państwa widziano jako przedstawiciela państwa politycznie przed nikim nie odpowiadającego. Przewidywano dlań jednak odpowiedzialność konstytucyjną ${ }^{11}$. Jak tłumaczył W. Komarnicki „Prezydent nie może być odpowiedzialny ani politycznie ani parlamentarnie, bo to nie godziłoby się z jego stanowiskiem niezależnego organu państwowego, ale powinien być odpowiedzialny konstytucyjnie za przekroczenie tej delegacji, którą jako głowa państwa od Narodu otrzymał. Dlatego w konstytucji powinno być zastrzeżenie, że za złamanie konstytucji Prezydent jest odpowiedzialny"12.

Za poważny problem uznano sam sposób wyboru prezydenta. Uważano, że aby prezydent należycie wypełniał swoje obowiązki, instytucja głowy państwa powinna znaleźć się w ręku właściwej osoby, która pojmowałaby swoje obowiązki zgodnie $\mathrm{z}$ dobrem i interesem narodu. Idąc tym tropem, szczególnie sprzeciwiano się propozycji wyboru prezydenta $\mathrm{w}$ drodze głosowania o charakterze powszechnym ${ }^{13}$. Tym bardziej było to istotne zagadnienie, że jak wskazywano wielokrotnie, polskie społeczeństwo prezentowało niski poziom kultury politycznej. Powtarzano opinie o politycznej niedojrzałości społeczeństwa, nie dość wystarczająco orientującego się w zagadnieniach publicznych. Ważnym argumentem była możliwość udziału w wyborach ludności niepolskiej, a zwłaszcza żydowskiej. Uważano, że głowa państwa powinna cieszyć się należytą powagą i szacunkiem, a tego nie gwarantował wybór drogą bezpośrednią. Reprezentanci młodych dosyć sceptycznie oceniali zasadę ludowładztwa. Za szkodliwe rozwiązanie uważano instytucję referendum lu-

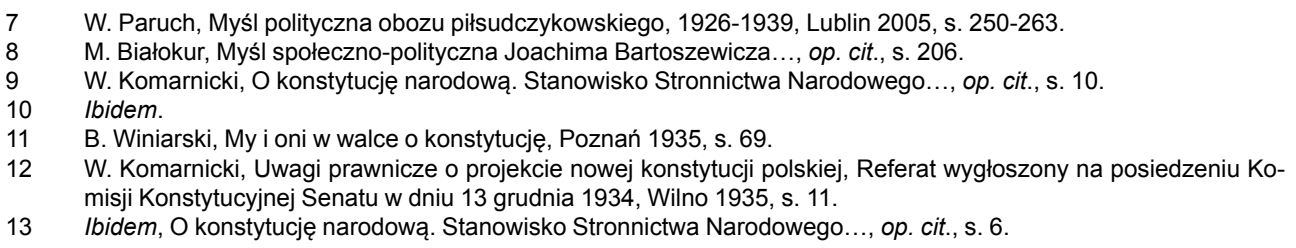


dowego. Idąc tym tropem, wybór głowy państwa dokonany w drodze głosowania powszechnego był uważany za rozwiązanie wielce szkodliwe. Takie przekonania wyraźnie wyartykułował między innymi Ryszard Piestrzyński, który pisał: „Stronnictwo Narodowe chce punkt ciężkości przenieść z „ludu” na bardziej określony naród polski" ${ }^{14}$.

W myśli politycznej SN często pojawiały się odwołania do przeszłości polskiego narodu i państwa ${ }^{15}$. Czerpiąc $z$ dotychczasowych doświadczeń polskiej państwowości przywoływano wydarzenia z okresu przedrozbiorowego, które dawały naukę na przyszłość: „Smutne doświadczenia z przedrozbiorową elekcją viritim dostatecznie przekonują nas, że wybór prezydenta w drodze plebiscytu nie przysporzyłby powagi głowie państwa, ale za to otworzyłby na oścież drogi do wpływu na ten wybór obcym mocarstwom i obcym międzynarodowym czynnikom"16. Obawiano się zwłaszcza głosów ludności niepolskiej, w wyniku których urząd głowy państwa znalazłby się w ręku nieodpowiedniej jednostki. Poważnym argumentem, było przekonanie, że wybór w drodze bezpośredniej umocniłby pozycję ugrupowań politycznych o obliczu lewicowym i przedstawicieli mniejszości narodowych ${ }^{17}$. Jak dowodził publicysta „Awangardy”, „Wybór prezydenta przez powszechne głosowanie nie gwarantuje bynajmniej przewagi żywiołów dośrodkowych - wprost przeciwnie, stwarza w naszych warunkach niemal pewność, że władza prezydencjalna spoczywać będzie w rękach żywiołów odśrodkowych - skrajnej lewicy wespół $\mathrm{z}$ mniejszościami ${ }^{18}$. Uważano, że wybory powszechne łączyły się z walką polityczną. Obawiano się także rywalizacji politycznej, która miała osłabiać autorytet tego urzędu. „(...) Wreszcie wybór prezydenta Rzeczypospolitej przez powszechne głosowanie rozpętałby za każdym razem falę najdzikszej demagogii, która miałaby charakter o wiele jeszcze groźniejszy niż demagogia uprawiana przez stronnictwa polityczne przy wyborach do ciał ustawodawczych. (...) Wymienione względy wystarczą chyba do uznania projektu wprowadzenia w Polsce systemu prezydencjalnego z wyborem prezydenta przez powszechne głosowanie za możliwie najgorszą i najmniej fortunną próbę reformy naszego ustroju"19. Zdaniem R. Piestrzyńskiego powszechne wybory prezydenckie prowadziłyby do rozwoju negatywnych zjawisk politycznych i społecznych, a zwłaszcza takich jak: korupcja, politykierstwo, łapownictwo. Pisał o tym następująco: „Przekazując wybór głowy państwa masom, system ten stoi w sprzeczności z dążeniami do hierarchizacji społeczeństwa i wytworzenia elity. Daje natomiast pole do demagogii, rozwydrzenia, korupcji. Dla Pol-

R. Piestrzyński, Podstawy nowoczesnego i narodowego ustroju, „Awangarda” 1929, nr 4, s. 73.

Zob.: S. Godlewski, Nie wskrzeszajmy żywych, „Myśl Narodowa” 10 I 1937, nr 2, s. 22, 23; J. Rembieliński, Na widowni, „Myśl Narodowa” 30 VI 1934, nr 28, s. 408; P. Jastrzębski, Myśl Narodowa 1921-1939. Studium politologiczno-prasoznawcze, Warszawa 2012, s. 130.

W. Komarnicki, O konstytucję narodową. Stanowisko Stronnictwa Narodowego..., op. cit., s. 6. Ibidem.

(sw.), Uwagi, „Awangarda” 1928, nr 5-6, s. 148.

Ibidem. 
ski przy jej słabym wyrobieniu politycznym i wobec istnienia mniejszości ustrój taki byłby fatalny. Byłby to powrót do czasów elekcji króla i do pacta conventa, które nas do zguby doprowadziły" ${ }^{20}$. Uważano, że wybór prezydenta w drodze wyborów powszechnych mógłby też ułatwić obcym i jak mniemano wrogim, czynnikom wpływ na sytuację wewnętrzną w państwie polskim. Wobec tak licznych argumentów domagano się wyboru prezydenta przez Zgromadzenie Narodowe.

Liderzy SN nie aprobowali stanu prawnego wprowadzonego po 1935 roku. Jak pisano już wyżej, powodem niechęci była możliwość wyboru na to stanowisko polityka reprezentującego formację piłsudczykowską. Powyższy stan rzeczy interpretowano jako zastąpienie idei republikańskiej zasadą, ,jedynowładztwa, czyli monarchicznej"21. W wypowiedziach publicystów domagających się wzmocnienia władzy wykonawczej zwracano jednocześnie uwagę na sposób wyboru prezydenta. Ryszard Piestrzyński proponował jego wybór przez specjalne kolegium, w skład którego obok reprezentantów izb ustawodawczych wchodziliby także przedstawiciele samorządów ${ }^{22}$.

W myśl projektu konstytucyjnego zaproponowanego przez SN, kadencja prezydenta miałaby trwać 7 lat. Wybrany na prezydenta mógł być wyłącznie obywatel Rzeczypospolitej, posiadający zdolność wybieralności do Senatu. Prezydent miał być wybierany przez Zgromadzenie Narodowe. Wybór prezydenta miałby zostać dokonany się bezwzględną większością głosów przez obie izby parlamentu, czyli Izbę Poselską i Senat w sposób połączony. Obowiązek zwołania obu izb w celu dokonania wyboru głowy państwa miał urzędujący prezydent Rzeczypospolitejej.

W przypadku, gdyby prezydent Rzeczpospolitej Polskiej nie mógł sprawować urzędu oraz w razie opróżnienia urzędu prezydenta wskutek śmierci, zrzeczenia się lub innej przyczyny, miał zastąpić go Marszałek Sejmu, a w razie braku takiej możliwości - Marszałek Senatu. Jeżeli prezydent Rzeczypospolitej Polskiej przez 3 miesiące nie sprawował urzędu, marszałek Izby Poselskiej albo w jego zastępstwie marszałek Senatu miał obowiązek zwołać bezzwłocznie Sejm i poddać uchwale obu izb połączonych czy urząd prezydenta należy uznać za opróżniony ${ }^{24}$.

Reprezentanci starego pokolenia nie kryli obaw przed wyposażeniem głowy państwa w nadmierne uprawnienia. Uważano, że kompetencje prezydenta nie powinny ograniczać władzy rządu ani osłabiać kontrolnej roli parlamentu ${ }^{25}$. Jak do-

20 R. Piestrzyński, Kryzys ustrojowy i jego rozwiązanie, „Awangarda” 1928, nr 7, s. 167.

21 B. Sprengel, Nowela sierpniowa a kryzys demokracji parlamentarnej, (w:) Kryzysy i sposoby ich przezwyciężania w myśli politycznej XX wieku, Studia i szkice, W. Wojdyła (red.), Toruń 2004, s. 139-156; P. Jastrzębski, Konstytucja Kwietniowa 1935 roku w świetle publicystyki „Myśli Narodowej”, (w:) Silna demokracja w silnym państwie. Koncepcje reformy ustroju politycznego państwa w publicystyce politycznej XX wieku, J. Faryś, T. Sikorski, P. Słowiński (red.), Gorzów Wielkopolski 2007, s. 105-120.

22 R. Piestrzyński, Naród w państwie, Poznań 1934, s. 41.

23 W. Komarnicki, O konstytucję narodową. Stanowisko Stronnictwa Narodowego w sprawie rewizji konstytucji oraz tekst projektu rewizji złożonego przez Klub Narodowy w Komisji Konstytucyjnej Sejmu, Warszawa 1930, s. 10.

24 Ibidem.

25 W. Komarnicki, Wakacyjna dyskusja konstytucyjna, „Myśl Narodowa” 1 X 1928, nr 23, s. 361, 362; W. Komarnicki, Rząd czy prezydent, „Myśl Narodowa” 1929, nr 11, s. 166. 
bitnie pisał Z. Stahl „Niedołężnemu złu sejmu przeciwstawiono groźbę sprężystego i mocnego zła głowy państwa"26. W. Komarnicki przypominał, że uprawnienia prezydenta nie powinny: 1) ograniczać władzy rządu 2) przeszkadzać w wypełnianiu funkcji kontrolnej przez parlament. Sprzeciwiano się wyznaczaniu przez ustępującego prezydenta swojego następcy, gdyż mogłoby to doprowadzić do zatargów partyjnych o tę godność, stałoby się podstawą do rozwoju matactw, korupcji, intryg politycznych i zatargów personalnych.

Upowszechniano pogląd, że prezydent nie może być odpowiedzialny ani politycznie ani parlamentarnie. Uważano, że byłoby to sprzeczne z jego stanowiskiem niezależnego organu państwowego. Wyrażano pogląd o konieczności konstytucyjnej odpowiedzialności prezydenta. Jak pisał W. Komarnicki w Konstytucji powinien znaleźć się zapis, że za złamanie Konstytucji prezydent ponosi odpowiedzialnośćc ${ }^{7}$.

W enuncjacjach przedstawicieli zarówno starego, jak i młodego pokolenia SN trwale zapisał się postulat wprowadzenia silnej władzy państwowej. Idea silnych rządów nie była jednak zbieżna $z$ postulatem władzy absolutnej ${ }^{28}$. Poprzez silne rządy rozumiano raczej rządy praworządne, skuteczne, sprawowane w imię wartości narodowych i zgodnie $\mathrm{z}$ interesem narodowym. Wielokrotnie wysuwany postulat silnego rządu przejawiał się w konkretnych propozycjach ustrojowych. SN opowiadało się za takimi rozwiązaniami, które miały uniemożliwić obalenie rządu poprzez przypadkową większość w Sejmie. „Rząd silny jest wtedy, gdy ma w ręku potrzebne środki rządzenia, gdy nie jest krępowany ani paraliżowany przez czynniki do rządzenia niepowołane i nieodpowiedzialne, gdy ma autorytet moralny" ${ }^{29}$. W celu umocnienia pozycji rządu postulowano wprowadzenie takiego przepisu, który by zapobiegał możliwości obalenia rządu przypadkową większością w Sejmie ${ }^{30}$.

Najlepszą władzę stanowiła elita narodowa złożona $\mathrm{z}$ najwartościowszych jednostek, które w codziennym działaniu kierowały się dobrem narodowym. Jednak władza nawet wówczas, gdy sprawowała ją elita narodowa, musiała mieć wyznaczone granice prawne i polityczne. Postulat praworządności na stałe wpisał się w myśl polityczną Narodowej Demokracji. Uważano, że potrzebna jest kontrola nad sprawującymi władzę. Argumentowano, że „Rząd niekontrolowany i uchylający się od kontroli i odpowiedzialności nie będzie miał należytej powagi”. Uważano, że niezbędna jest całkowita odpowiedzialność ministrów ${ }^{31}$.

Podkreślano potrzebę wzmocnienia pozycji rządu i administracji państwowej. Stałym postulatem było dążenie do uniezależnienia rządu od przypadkowej większości w Sejmie. SN wysuwało postulat, aby wniosek o pociągnięcie rządu do odpowiedzialności był odpowiednio umotywowany, podpisany przez $1 / 4$ ustawowego

Z. Stahl, Odebrać ludności - oddać narodowi, „Awangarda” 1929, nr 4, s. 71.

W. Komarnicki, Uwagi prawnicze o projekcie nowej konstytucji, Wilno 1935, s. 11.

R. Piestrzyński, Kryzys ustrojowy i jego rozwiązanie, „Awangarda” 1928, nr 7, s. 165, 166.

B. Winiarski, My i oni w walce..., op. cit., s. 70.

W. Komarnicki, O Konstytucję narodową..., op. cit., s. 11.

B. Winiarski, My i oni w walce..., op. cit., s. 70. 
składu Izby Poselskiej lub Senatu. Taki wniosek mógł być poddany pod głosowanie nie wcześniej niż po upływie 8 dni od chwili jego wniesienia. Działalność rządu powinna być zgodna z wolą reprezentacji narodowej. Rada Ministrów miała opierać się na większości parlamentarnej, która miała obowiązek rozliczać ministrów z realizacji programu politycznego. Parlament miałby kontrolować, czy ministrowie nie łamią prawa ${ }^{32}$.

Sprzeciwiano się próbom utożsamiania rządu z państwem. Stronnictwo Narodowe wyraźnie odrzucało dominację interesów politycznych nad ogólnym dobrem państwa. Pomimo zdecydowanej krytyki formacji piłsudczykowskiej koncepcje ideologów SN nie zmierzały ani w kierunku destrukcji prac kolejnych rządów, ani do zdestabilizowania sytuacji w państwie. Przykładem odpowiedzialności za państwo w kontekście prawnego umocowania Rady Ministrów może być zawarta w dokumentach programowych SN z 1928 roku, propozycja, której celem, było znaczne ograniczenie możliwości uchwalania votum nieufności dla rządu. Stronnictwo Narodowe, zdecydowanie krytykując Piłsudskiego, nie posuwało się jednak do osłabiania fundamentów ustroju politycznego państwa.

W myśli politycznej SN nie koncentrowano się na zagadnieniach związanych ze sposobami wyłaniania Rady Ministrów i funkcjonowania gabinetu. Skupiano się głównie na podkreślaniu znaczenia praworządności i na krytyce poczynań rządów utworzonych przez obóz piłsudczykowski.

\section{BIBLIOGRAFIA}

Bartoszewicz Joachim. 1928. „Ustrój władz w państwie”. Myśl Narodowa 13: 265-267.

Białokur Marek. 2005. Myśl społeczno-polityczna Joachima Bartoszewicza. Toruń: Wydawnictwo Adam Marszałek.

Godlewski Stefan. 1937. „Nie wskrzeszajmy żywych”. Myśl Narodowa 2: 22-23.

Jastrzębski Przemysław. 2007. Konstytucja Kwietniowa 1935 roku w świetle publicystyki „Myśli Narodowej". W Silna demokracja w silnym państwie. Koncepcje reformy ustroju politycznego państwa w publicystyce politycznej XX wieku, 105-120. Gorzów Wielkopolski: Wydawnictwo Państwowej Wyższej Szkoły Zawodowej.

Jastrzębski Przemysław. 2012. Myśl Narodowa 1921-1939. Studium politologiczno-prasoznawcze. Warszawa: Wydawnictwo Instytutu Pamięci Narodowej. Komisja Ścigania Zbrodni przeciwko Narodowi Polskiemu.

Komarnicki Wacław 1929. „Rząd czy prezydent”, Myśl Narodowa 11: 166-168.

Komarnicki Wacław. 1928. „Wakacyjna dyskusja konstytucyjna”. Myśl Narodowa 23: 361-363. 
Komarnicki Wacław. 1930. O konstytucje narodową. Stanowisko Stronnictwa Narodowego w sprawie rewizji konstytucji oraz tekst projektu rewizji złożonego przez Klub Narodowy w Komisji Konstytucyjnej sejmu, Warszawa: Wydawnictwo Zarządu Głównego Stronnictwa Narodowego.

Komarnicki Wacław. 1935. Uwagi prawnicze o projekcie nowej konstytucji polskiej, Referat wygłoszony na posiedzeniu Komisji Konstytucyjnej Senatu w dniu 13 grudnia 1934. Wilno: Wydawnictwo Księgarnia Józefa Zawadzkiego.

Koziełło Tomasz. 2011. Idea parlamentaryzmu w koncepcjach politycznych Narodowej Demokracji (1918-1939), W Ustrój państwa w polskiej myśli politycznej XX-XXI wieku, 29. Wydawnictwo Naukowe Uniwersytetu Mikołaja Kopernika.

Majchrowski Jacek Maria. 1988. Nacjonalizm jako sposób myślenia. W Prawo i polityka, 358. Warszawa: Państwowe Wydawnictwo Naukowe.

Paruch Waldemar. 2005. Myśl polityczna obozu piłsudczykowskiego 1926-1939. Lublin: Wydawnictwo Uniwersytetu Marii Curie-Skłodowskiej.

Piestrzyński Ryszard. 1928. „Kryzys ustrojowy i jego rozwiązanie”. Awangarda 1928, nr 7: 164-167.

Piestrzyński Ryszard. 1929. „Podstawy nowoczesnego i narodowego ustroju”. Awangarda 4: 73-75.

Piestrzyński Ryszard. 1934. Naród w państwie. Poznań: Wydawnictwo Awangardy.

Radomski Grzegorz. 2009. Samorząd terytorialny w myśli politycznej Narodowej Demokracji 19181939. Toruń 2009: Wydawnictwo Naukowe Uniwersytetu Mikołaja Kopernika.

Rembieliński Jan. 1934. „Na widowni”. Myśl Narodowa 28: 408-410.

Sprengel Bolesław. 2004. Nowela sierpniowa a kryzys demokracji parlamentarnej. W Kryzysy i sposoby ich przezwyciężania w myśli politycznej XX wieku, Studia i szkice, 139-156. Wydawnictwo Uniwersytetu Mikołaja Kopernika.

Stahl Zdzisław. 1929. „Odebrać ludności - oddać narodowi”, Awangarda 4: 71-73.

Winiarski Bohdan. 1935. My i oni w walce o konstytucję. Poznań: Wydawnictwo S. A. „Ostoja”. 


\section{THE POLITICAL POSITION OF EXECUTIVE POWER IN THE LIGHT OF THE VIEWS OF THE IDEOLOGISTS OF THE NATIONAL PARTY UP TO 1939}

During the interwar period, most European countries had a tendency to modify Montesquieu's assumptions on the tripartite separation of power into the legislature, the executive, and the judiciary. The adaptation of the existing political solutions led to the strengthening of the executive bodies. The political opinions of the National Party may be considered as a reflection of these processes. Underlying the National Party's attitude towards executive bodies was the idea of the need to create a national political system. Having reflected on the nature of the executive bodies, they came to the conclusion that these bodies should guarantee the strength of government and its rightful authority. The National Party advocated the introduction of constitutional solutions which would 1) secure the continuity and stability of the government; 2) prevent too-frequent changes of the government. The National Party's project supported the principle of the political responsibility of government. The National Party advocated the idea of extending the powers of the president. Giving the president the power of legislative veto was considered a necessity. It was also believed that the president should strengthen his position through active participation in the works of the government.

Keywords: executive power, political thought, National Party

Słowa kluczowe: myśl polityczna, władza wykonawcza, Stronnictwo Narodowe 